\title{
Zygmunt CHELKOWSKI
}

Fish biology

\author{
SEA TROUT (SALMO TRUTTA L.) AND SALMON (SALMO SALAR L.) \\ CATCHES IN THE LOWER ODRA RIVER SYSTEM AS WELL AS STOCKWNG \\ IN THE YEARS 1973-1987 \\ POLOWY TROCI (SALMO TRUTTA L.) I LOSOSIA (SALMO SALAR L.) \\ W SYSTEMIE DOLNEJ ODRY ORAZ ZARYBIANIE W LATACH 1973-1987
}

Academy of Agriculture, Szezecin

\begin{abstract}
The paper presents and analyzes catches of sea trout and salmon in the lower Odra river system during the period of 19731987. Both of the fish species had to be treated jointly for complying with the economic statistics, having been the source of information concerning the catches. The variations of catches were taken into account with regard to years, months as well as regional division. Moreover data were accumulated as to the stocking of the lower Odra water system with sea trout and salmon during the period of studying the catches.
\end{abstract}

\section{INTRODUCTI ON}

Sea trout (Salmo trutta L.) and salmon (Salmo salar L.) are found to appear in the lower Odra system that belongs in part to Poland and Germany (Fig. 1). Studying the catches of the two economically valuable fish species against the background of stocking accomplished in this water region over the period of 15 years (1973-1987) constitutes the purpose of the actual elaboration. The provided results are undestood to be the continuation of the selfsame investigations by Chelkowski et al. (1976) encompassing primarily the years from 1960 to 1972 . Thus, the comparison of catches and the stocking effects involving the two periods may turn out to be an interesting problem, not only as exploratory, but also as economical one. Both of these fish species had to be treated jointly as it has been done in the economical statistics, the latter being the source of information concerning the catches. The estimation of species composition in catches is compiled separately, although covering merely the time-span 


\section{1.}

$\therefore$.

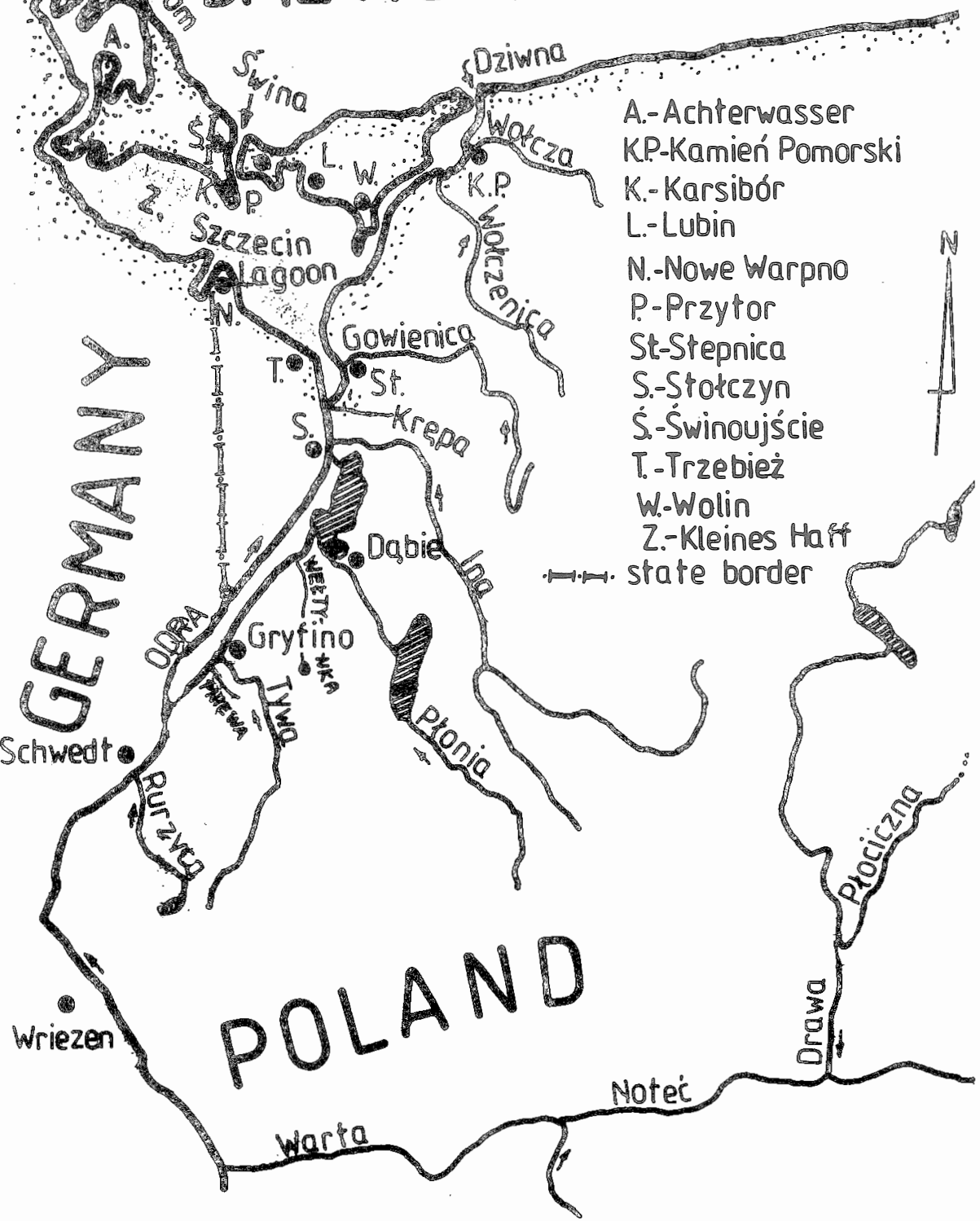

Fig. 1. The lower Odra and Szczecin Firth basin 
of 1973-1977 and referring to Polish waters only (Cherkowski et a. 1976, 1977, 1978, 1979, 1980). According to Chelkowski (1987) the mass, in the Szczecin Firth and in the lower Odra, was made up of $93.2 \%$ of sea trout and $6.8 \%$ salmom, in the mentioned years. The elaboration furnishes the variations in catches efiected by Polish and German lishermen, arranged in years, months and divided into regions. Investigation of catches proceeding in such a manner may indicate the route, period and intensity of spawning migrations of sea trout and salmon, having grown on the sea feeding grounds, and in water of the lower Odra system.

\section{MATERIAL AND METHOD}

The investigations covered the catches of grown sea trout and salmon from the Szczecin Firth and the lower Odra as well as Drawa Rivers. In the majority of cases the fishes were just in the decisive act of spawning migration, and also at the period of post-spawning and spawning migration.

The Szczecin Firth forms a water area confined by the mouth of Krępa Ilowing into the Odra river and Dziwna, Swina, Piana with the outlet. to the Baltic Sea. The lower Odra is the river segment that is contained between the mouth of Warta and that of Krępa including the Lake Dabie (Chelkowski et al. 1976) (Fig. 1). The elaboration incorporates also salmon catches in Drawa being the Odra tributary of the IV order. The Szczecin Firth spreads out over 87881 ha whereof 46784 ha $(53.2 \%)$ belong to Poland, and 41097 ha (46.8\%) to Germany. The lower Odra claims 9320 ha, with 8383 ha (89.9\%) belonging to Poland and 937 ha (10.1\%) to Germany (Cheilkowski et al. 1976). The entire Szczecin Firth lies in the territory of Poland.

The basic statistical material consisted of fintncial documents, which provided pieces of information specifying the mass of salmon and sea trout caught by fishermen of : respective regions. Fishing data stemming from cooperative and individual fishermen, and referring to the Polish part of the Szczecin. Firth as well as the lower Odra were obtained at the fish purchasing centres run by the "Certa" Work Cooperative Fishery and Fish Processing at Kamien, Swinoujsicie, Przytorze, Stolczyn, Dabie and also by "Regalica" Fishery Work Cooperative at Gryfino. Use was also made of German fishing materials pertaining to the Szczecin Minor Firth (Kleines Hafi) and Piana with the adjacent waters (Peenestrom und Achterwasser) filed at Fischereiauisichtsam der DDR in Rostock, and relating to the lower Odra, being preserved in Produktions. genossenschaît der Binneníscher: "Freundschaft" - Schwedt (Oder) as well as Produktionsgenossenschaft der Binnenisscher - Wriezen - ZBE Satzlischproduktion Frankiurt (Oder). Quantities of salmon catches in Drawa were taken from the elaborations: Cheilkowska, Cheikowski (1974, 1975, 1976) and Cheikowski (1977).

The Polish fishermen catch salmon and sea trout in the Szczecin Firth and in the lower Odra accidentally, together with other fish species, using various lishing gear, 
prevalently box traps and gill nets (Chełkowski 1987). On the other hand salmon in Drawa were caught by resorting to trammel nets (Chełkowski 1971). Salmon and sea trout were delivered to purchasing centres, the weight was recorded down to $0.1 \mathrm{~kg}$. The catch data of the German fishermen covered ungutted fish, while those of Polish fishermen concerned gutted fish i.e. deprived of viscera.

There are no data involving salmon and sea trout catches in Warta and Noteć rivers. In 1969-1972 salmon and sea trout also failed to appear in catches accomplished in those waters (Chełkowski et al. 1976).

Salmon and sea trout catches in the lower Odra, in the segment from the Warta mouth to the road bridge linking Szczecin with Dąbie, carried out by Polish and German fishermen, during the years of studies, were also small. In the remaining Odra water system, as it stands out from compiled.information, the sea trout and salmon, during period of studies, were in fact, not found in the catches.

There is : one exception evidenced in Bartel's information (1987), who mentioned a catch of tagged salmon in the Odra above the Warta mouth. During the period following the Second World War, neither salmon nor sea trout were detected in the catches from Odra above the Warta mouth (according to Chełkowski et al. 1976). The statistical materials'omitted mentioning the rainbow trout (Salmo gairdneri Rich.).

Information about the lower Odra system being stocked with young sea trout and salmon in the years from 1973 to 1987 originated from fish-stocking campaign protocols, kept in Salmon Management Laboratory of Agriculture Academy in Szczecin, as well as elaborations: Bartel, Zielinski for the years 1973-1985; Chełkowska, Chetkowski 1974, 1975, 1976 and Chełkowski 1977. In the other waters of the Odra system in the years the catches were analyzed, no campaigns of releasing young salmon and sea trout were undertaken.

\section{CATCHES IN THE LOWER ODRA SYSTEM}

On the basis of assembled and elaborated material, the catches of salmon and sea trout in the lower Odra system, in the years $1973-1987$, claimed the total of $69675 \mathrm{~kg}$, there of $57584 \mathrm{~kg}$ were caught in the Szczecin Firth, $11757 \mathrm{~kg}$ in the lower Odra and as many as $354 \mathrm{~kg}$ in Drawa river (Table 1). The catches of salmon and sea trout in the lower Odra system, in the successive years of studies, oscillated within rather wide limits from $1936 \mathrm{~kg}$ in the year 1977 to $9581 \mathrm{~kg}$ in the year 1984. The average annual catch amounted to $4644.6 \mathrm{~kg}$.

Changes in the size of salmon and sea trout catches in the lower Odra system, during the fifteen-year-long studies, are presented in the form of linear regression (Romanowski 1951).

$$
y=a+b \cdot t
$$


Catches (kg) of seอ trout and salmon in the lower Odra รyรter in $1973-1983$

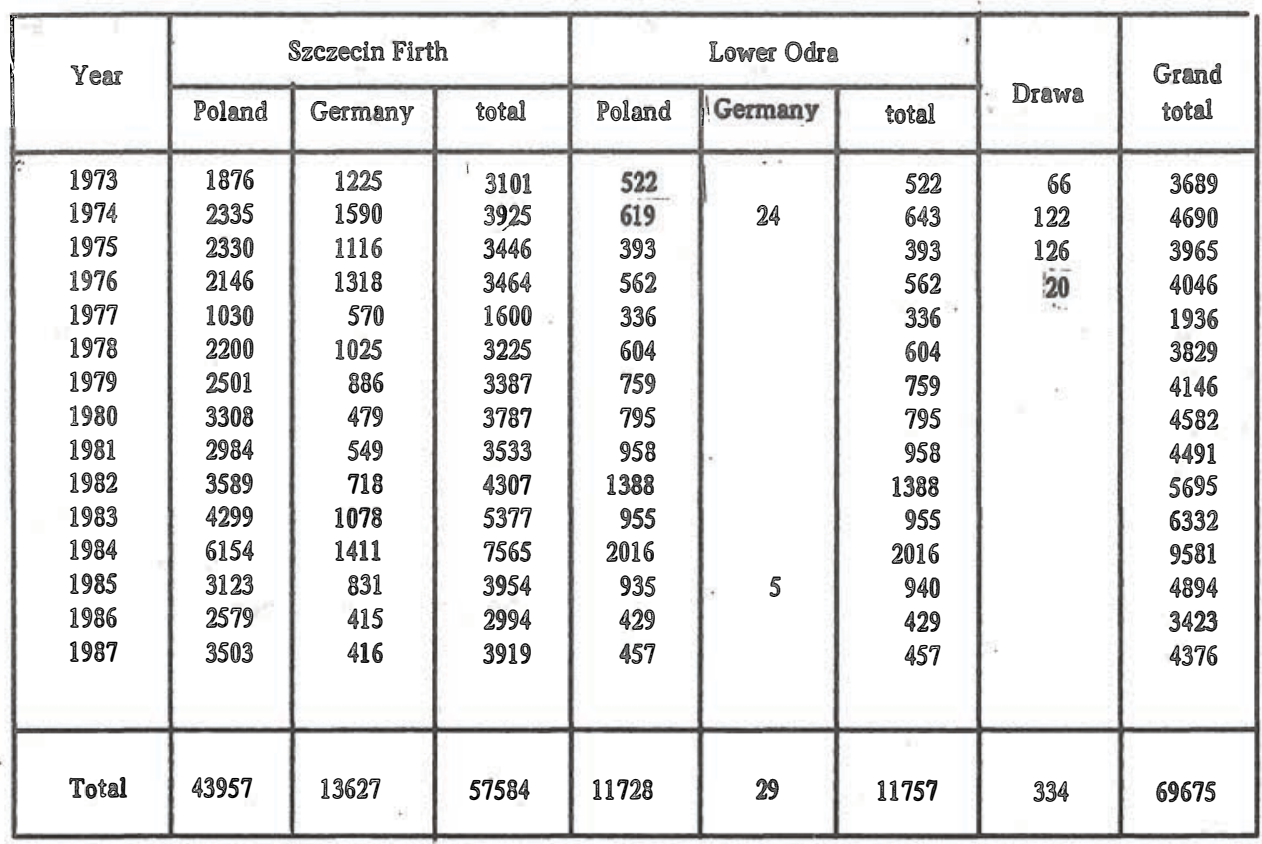

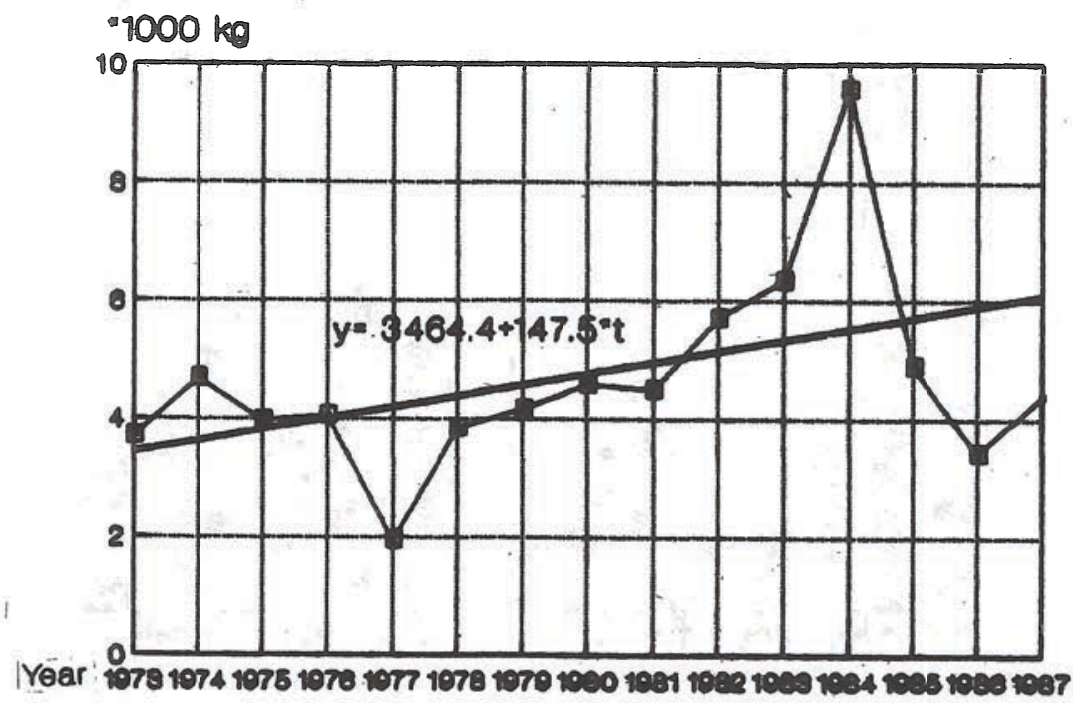

Fig. 2. Amounts of salmon and sea trout cought in the lower Odra system oves 1973-1987 
where $y$ - catch, $t$ - year (in calculation the year $1973=1 ; 1974=2 ; 1975=3$ $1987=15$ (and the following equation was obtained

$$
y=3464.4+147.5 \cdot 1
$$

the regression coefinicient $b=+147.5$ is indicating that despite considerable fluctua tions the catches displayed tendency to increase, while their average annul increment was about $148 \mathrm{~kg}$ (Fig. 2).

\section{CATCHES IN THE SZCZECIN FIRTH}

Salmon and sea trout catches in the entire Szczecin Firth in the years 1973-1987, exhibited substantial fuctuaction from $1600 \mathrm{~kg}$ in 1977 to $7565 \mathrm{~kg}$ in 1984 (Tab. 1). Hence the average annual catch of salmon and sea trout in the Szczecin Firth reached $3839 \mathrm{~kg}$. With a view to characterizing the feature of the annual catch of salmon and sea trout in the Szczecin Firth, the share of catches was worked out for the consecu. tive years of studies (Fig. 3). It was disclosed that the greatest annual share was $13.1 \%$, the lowest $2.8 \%$, out of the total catches effected during 15 -year period. Thus, the biggest annual catch was 4.7 times larger in relation to the lowest one.

In the years analyzed the salmon and sea trout catches in the German part of the Szczecin Firth amounted to 13627 (23.7\%) in the Polish one $43957 \mathrm{~kg}$ (76.3\%). The pertinent materials indicate that the Polish fishermen throughout all the years of studies did catch more salmon and sea trout than their German peers. Moreover, it may be found out that the carches effected by Polish fishermen in general showed, over

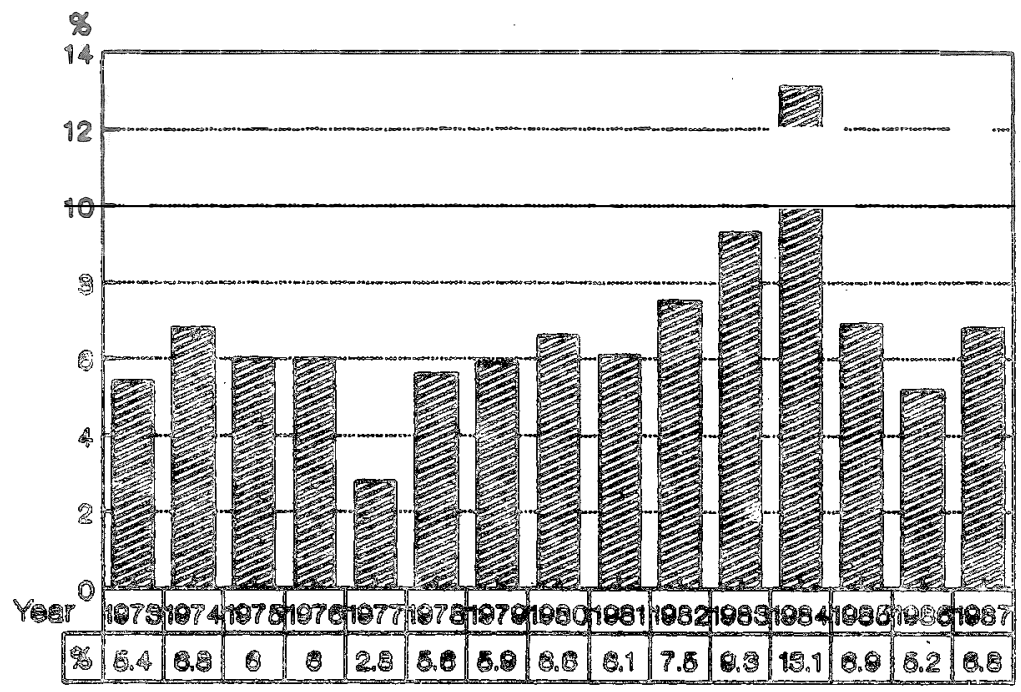

Fig. 3. Share of sea trout and salmon catches in Szczecin Firth in 1973-1987 (sum of catches (kg) during 1973-1987) assumed as $100 \%$ 


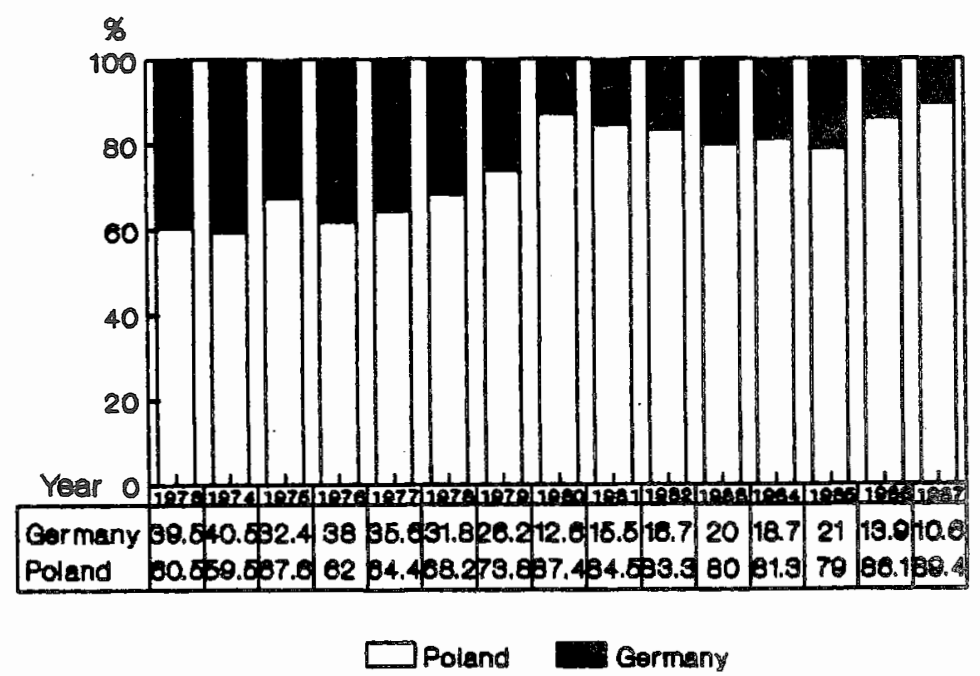

Fig. 4. Share of sea trout and salmon catches in Polish and German parts of Szczecin Firth in successive years of $1973-1987$

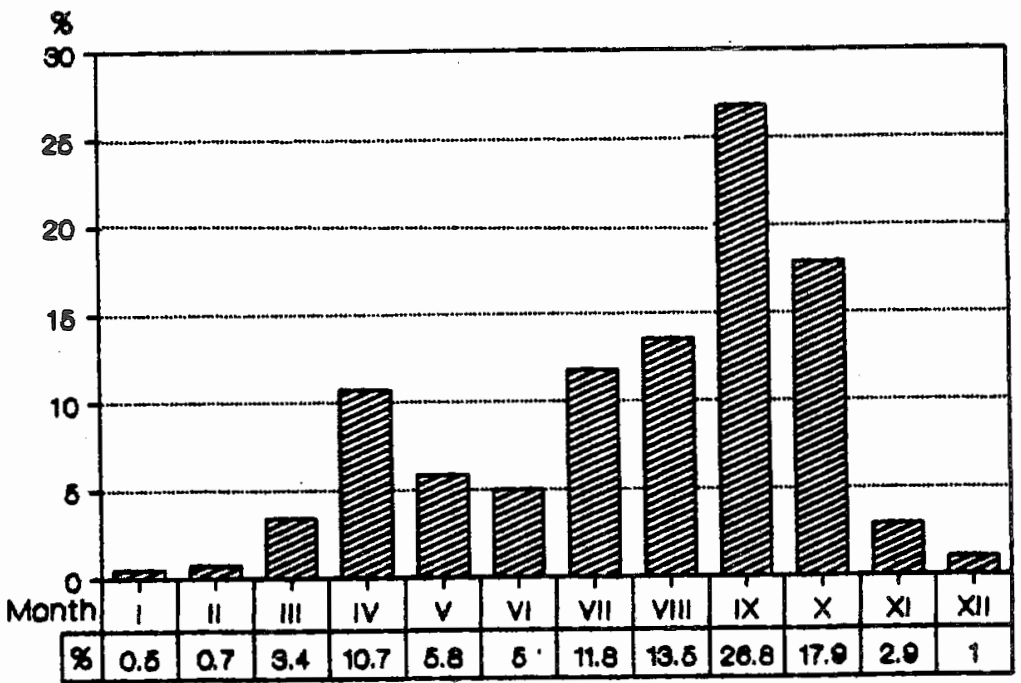

Fig. 5. Share of sea trout and salmon catches in Szczecin Firth in months of 1973-1987 (sum of catches $(\mathrm{kg}$ ) for 1973-1987 assumed as 100\%)

the study years, the tendency to increase, while that of German fishermen diminished (Fig. 4).

A further interesting cognative matter was to learn how the salmon and sea trout catches in the whole Szczecin Firth proceeded on the monthly scale (Fig. 5). As it appers firm the elaborated materials covering the entire period of studies, it is possible 
to distinguish 3 terms of catches: high ones occurring in July-October; medium recorded in April-June and lowe catches accomplished in November-March. The first period furnished $70 \%$ of catches the second $24.9 \%$; the third $5.1 \%$. The most pronounced share in catches was achieved in September (26.8\%), slightly lower in October (17.9\%), but the lowest share in the catches was evidenced in January (0.5\%). It is apparent from the shares in catches ascribed to individual months that there were two peaks of catches. The first is in April i.e. at the beginning of the spring, while the second takes place in September, thus, by the end of summer. The latter period of catches occurs in September 2 months prior to the start of spawning commencing in Gowienica, incorporated into the lower Odra system, in the month of November (Chełkowski 1966). The share in catches by German and Polish fishermen in Szczecin Firth in respective months of the year, reveals that the German fishermen catch more salmon and sea trout only in November, while in the remaining months higher catches are obtained by Polish fishermen (Fig. 6). It may be additionally noted that the share in catches by Germans in relation to Polish ones displays an increasing tendency in the months November-March, and decreasing trend at the period of April-October.

Moreover, elaboration was prepared to show the features of salmon and sea trout catches in regional divisions, separately for German and Polish parts of Szczecin Firth. In the Polish part of Szczecin Firth nine regions were established, and two for German part (Tab. 2).

The greatest contribution in salmon and sea trout catches in the Polish part of Szczecin Firth comes from regions of Kamien (38\%), Trzebież (27.2\%) and Lubin (15.3\%).

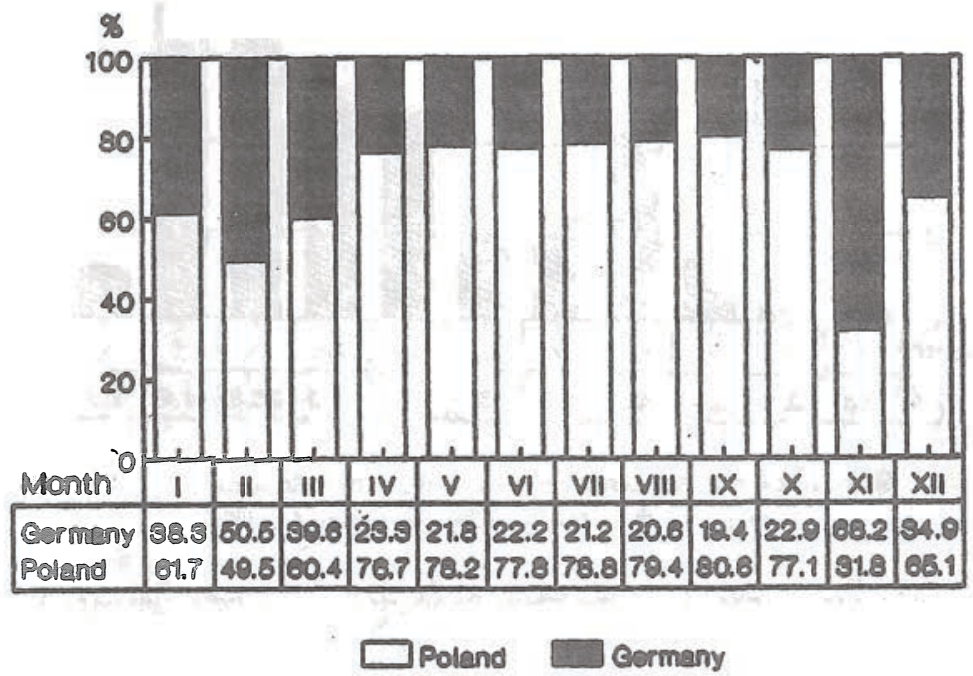

Fig. 6. Share of see trout and salmon cetches in Polish and German parts of Szcrecin Firth in months for 1973-1987 (sum of monthly caitches ( $\mathrm{kg}$ ) in consecutive years of 1973-1987 assumed as 100\%) 


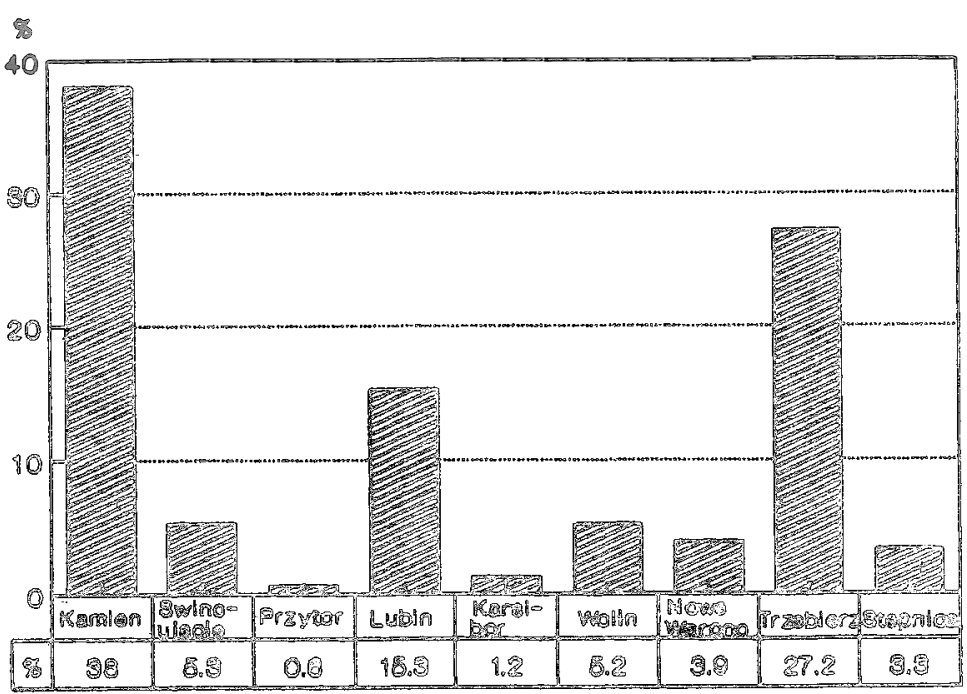

Fig. 7. Share of see trout and salmon catches in Polish part of Szczecin Fisth divided into regions for 1973-1987 (sum of carches (kg) is 1973-1987 assumed as 100\%)

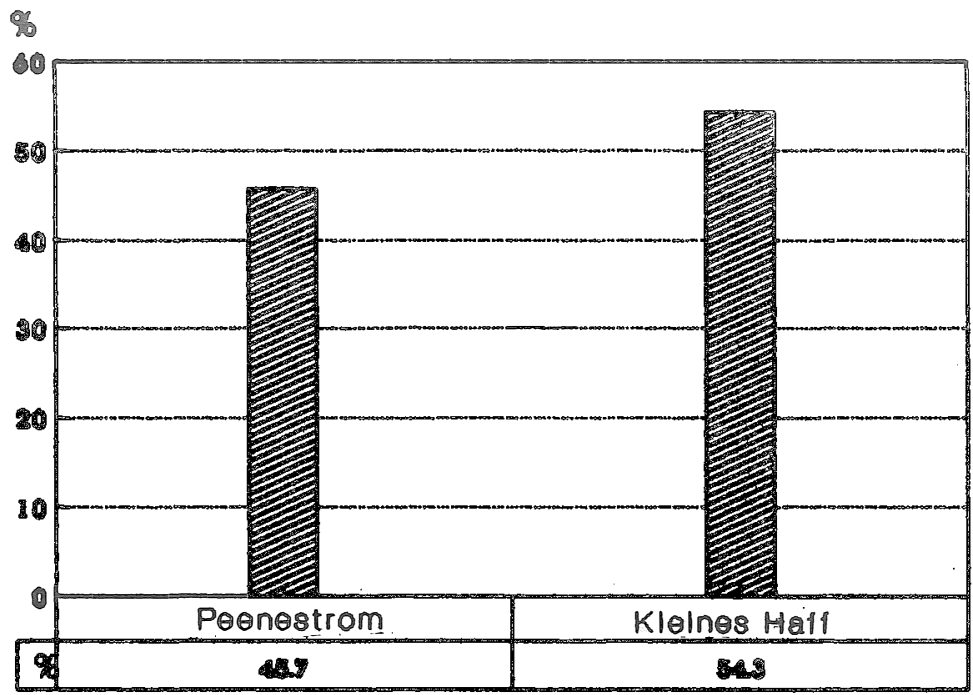

Fig. 8. Shøre of sę trout and salmon catches in German parł of Szczecin Firth divided inito regions for 1973-1987 (sum of carches (kg) in 1973-1987 assumed as 100\%)

The share in catches, however, in the other regions (Swinoujscie, Wolin, Nowe Warpno, Stepnica, Karsiborz, and Przytor) was significantly smaller. The share of the first three regions claims $80.5 \%$, that of the rest $-19.5 \%$ (Fig. 7 ).

In the German part of Szczecin Firth more considerable share of catches is attributed to the region of Minor Firth (54.3\%), and less outstanding to the region of Piana with the adjacent waters (45.7\%) (Fig. 8). 
Catches $(\mathrm{kg})$ of sea trout and salmon in the lower Odra system in 1973-1987 by regional division

\begin{tabular}{|c|c|c|}
\hline No & Region & $\mathrm{Kg}$ \\
\hline & \multicolumn{2}{|l|}{$\begin{array}{l}\text { Szczecin Firth } \\
\text { a. polish part }\end{array}$} \\
\hline $\begin{array}{l}1 . \\
2 . \\
3 . \\
4 . \\
5 . \\
6 . \\
7 . \\
8 . \\
9 .\end{array}$ & $\begin{array}{l}\text { Kamień Pomorski } \\
\text { Swinouj’scie } \\
\text { Przytor } \\
\text { Lubin } \\
\text { Karsibor } \\
\text { Wolin } \\
\text { Nowe Warpno } \\
\text { Trzebież } \\
\text { Stepnica }\end{array}$ & $\begin{array}{r}16683.4 \\
2351.3 \\
279.3 \\
6730.4 \\
530.5 \\
2277.2 \\
1720.9 \\
11953.0 \\
1431.0\end{array}$ \\
\hline \multicolumn{2}{|c|}{ Total } & 43957,0 \\
\hline & \multicolumn{2}{|l|}{ b. Germany part } \\
\hline $\begin{array}{l}1 . \\
2 .\end{array}$ & $\begin{array}{l}\text { Piana (Pennestrom and Achterwasser) } \\
\text { Mały Zalew (Kleines Haff) }\end{array}$ & $\begin{array}{l}6229.0 \\
7398.0\end{array}$ \\
\hline \multicolumn{2}{|c|}{ Total } & 13627.0 \\
\hline & \multicolumn{2}{|l|}{$\begin{array}{l}\text { lower Odra } \\
\text { 8. Polish part }\end{array}$} \\
\hline $\begin{array}{l}1 . \\
2 . \\
3 .\end{array}$ & $\begin{array}{l}\text { Stolczyn } \\
\text { Dagbie } \\
\text { Gryfino }\end{array}$ & $\begin{array}{r}6406.5 \\
5107.5 \\
213.6\end{array}$ \\
\hline \multicolumn{2}{|c|}{ Total } & 11727.6 \\
\hline \multicolumn{3}{|c|}{ b. Germany part } \\
\hline 1. & Schwedt, Wrizen, Frankfurt & 29.0 \\
\hline 1 . & Drawa & 334.0 \\
\hline
\end{tabular}

The presented data disclose that high salmon and sea trout catches appear at the Szczecin Firth outlet to the sea at Piana and Dziwna. The latter incorporates, due to its localization, the regions of Kamien and Wolin. The elaborated materials makes it apparent that the catches in Piana regions, during the period of studies, reached $6229 \mathrm{~kg}$; Kamien $16683 \mathrm{~kg}$; Wolin 2277 kg. Hence, Piana and Dziwna furnish 45.7\%, out of the overall salmon and sea trout catches in Szczecin Firth. 

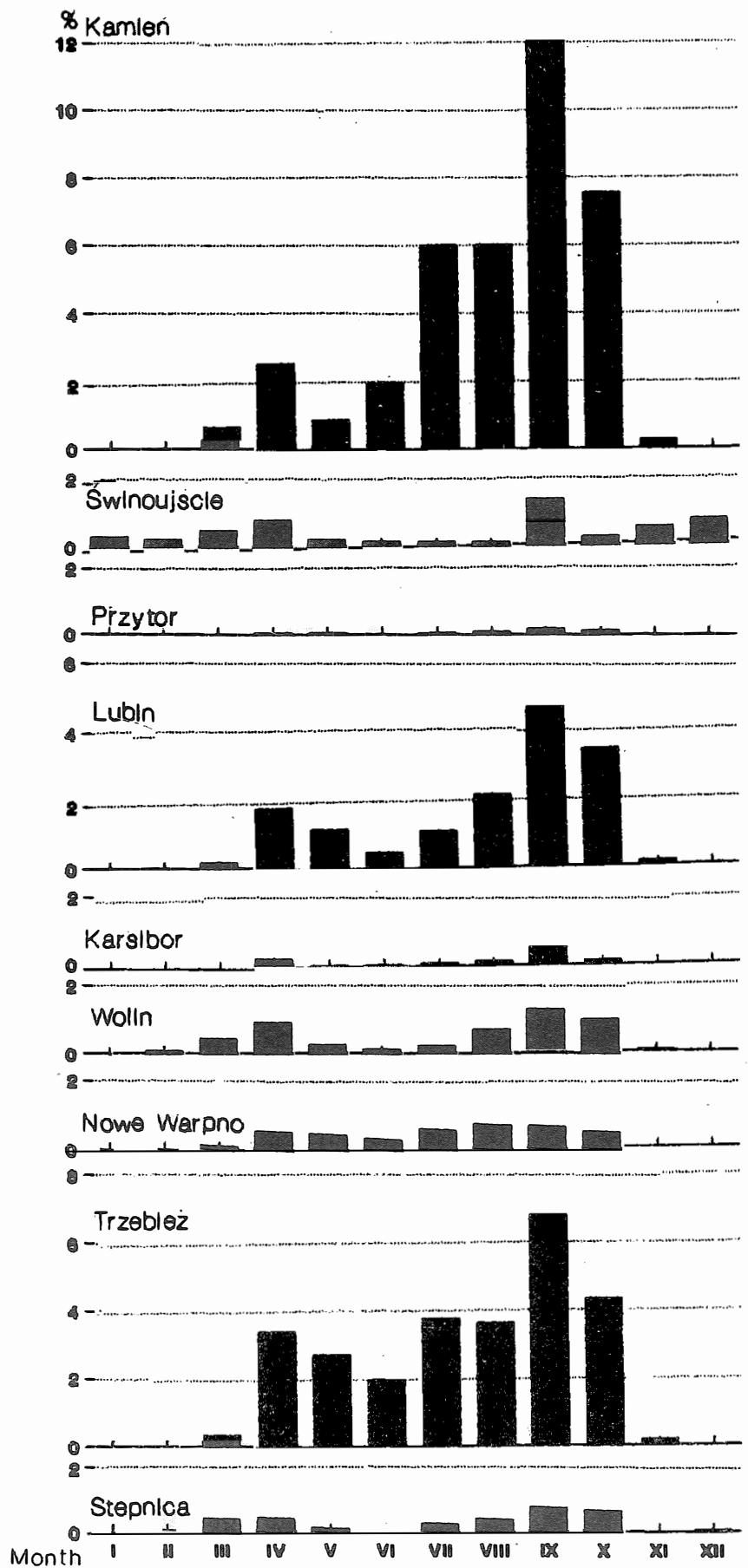

Fig. 9. Share of sea trout and salmon catches in Polish part of Szczecin Firth divided into regions and months for 1973-1987 (sum of catches (kg) for 1973-1987 assumed as 100\%) 


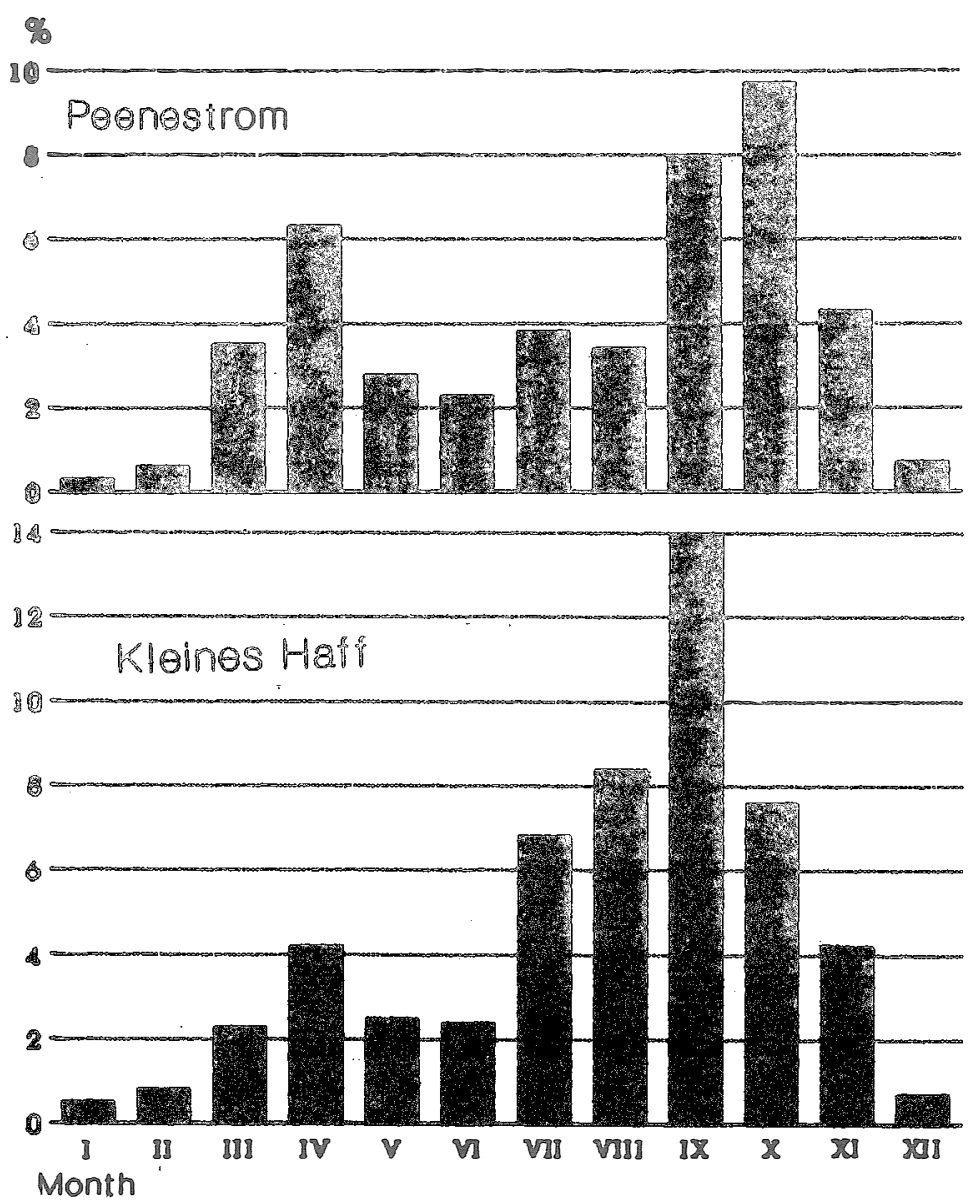

Fig. 10. Share of sea trout and salmon catches in German part of Szczecin Firth divided into regions and months for 1973-1987 (sum of catches (1kg) in 1973-1987 assumed as 100\%)

The next interesting and exploratory material was dealing with the share of the catches in the above-mentioned regions in monthly compilation. It is evident from the materials so elaborated that in the Polish part of Szczecin Firth, salmon and sea trout were caught in January, exclusively in the Swinoujscie region, it means close to the sea. In February cathing went on in Siwinoujscie, Wolin and Stepnica. From March to September salmon and sea trout were being caught in all regions of the Polish part of Szczecin Firth; at that displaying a rising tendency. The biggest share in catches carried out in all regions in the Polish part of Szczecin Firth is recorded in the month of September and somewhat smaller in October. More sizable shares in catches are still registered in July, August and April, while in May and June they are rather small. In the Kamien region the lowest share in catches was seen in May; in the remaining regions this holds true in June. In November and December the fishes of salmon and sea trout 
species - two-environmental-had, since 1986, been under protection in the Polish part of Szczecin Firth. That is the reason why their share was negligible or they did not appear in catches at all, except for Świnoujscie region (Fig. 9).

In the German part of Szczecin Firth, in the regions of Piana and Minor Firth salmon and sea trout were found in the catches throughout all the months of the year (Fig. 10). However, the share in catches at the beginming of the year i.e. in January and February was scanty. The share in catches accomplished during the consecutive six months of the year (from March to August) in the regions of Minor Firth and Piana displays an increasing tendency, and proceeds similarly as in other regions in the Polish part of Szczecin Firth. The top share in the catches in the region of Minor Firth in the same way as in all other regions of the Polish part of Szczecin Firth falls for September. As concerns the region of Piana, the catch peak occurs in October. In all the German and Polish regions of Szczecin Firth the catch peak is in the spring, namely in the month of April.

A minute share in catches effected in the regions of Piana and Minor Firth is recorded in June; hence to a similar extent as in the majority of regions in the Polish part of Szczecin Firth. Rather a high share in catches in the regions of Minor Firth and Piana is evidenced in November, but markedly lower in December, which fails to happen in the Polish part of Szczecin Firth. The period of protection in November and December is not obligatory for the German fishermen.

\section{CATCHES IN THE LOWER ODRA}

Sea trout and salmon were also found in catches carried out in the lower Odra, in the regions of Stołczyn, Dąbie, Gryfino, Szzwedt, Wriezen and Frankfurt. The catches of this fish over the consecutive years of studies oscillated within rather wide limits, from $336 \mathrm{~kg}$ to $2016 \mathrm{~kg}$ (Tab. 1). The mean annual catch was $784 \mathrm{~kg}$. The fluctuation of the annual catches is shown in the diagram (Fig. 11). The highest yearly share claimed $17.2 \%$ the lowest one $2.9 \%$ out of the total catches. Throughout the analyzed period, the largest catch was recorded in 1984, the soallest occurred in 1977, thus the pattern of catches was similar to that in Szczecin Firth.

The most massive catches came from the regions of Stolczyn and Dabie, in other words in the river-mouth segment of Odra, lying to the North of the road that links Szczecin with Dabie. In the cited two regions the salmon and sea trout catches for the fiften-year-long period amounted to $11514 \mathrm{~kg}$.

The catches of these fishes in the second part of the lower Odra located to the south of the mentioned road up to the Warta mouth, hence in the regions of Gryfino, Szwedt, Wrizen and Frankfurt were significantly smaller and totalled $242.6 \mathrm{~kg}$. The catches accomplished by Polish fishermen in this part of the lower Odra in the Gryfino region reached $213.0 \mathrm{~kg}(88 \%)$, and those effected by German fishermen in the regions of 


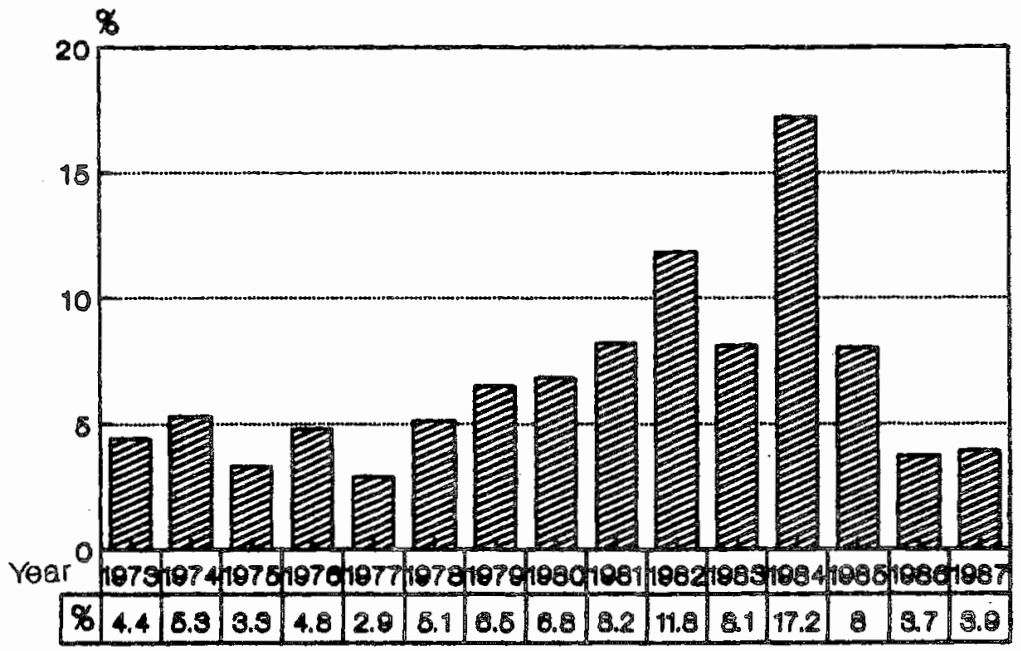

Fig. 11. Share of sea trout and salmon catches in the lower Odra in 1973-1987 (sum of catches (kg) for 1973-1987 assumed as 100\%)

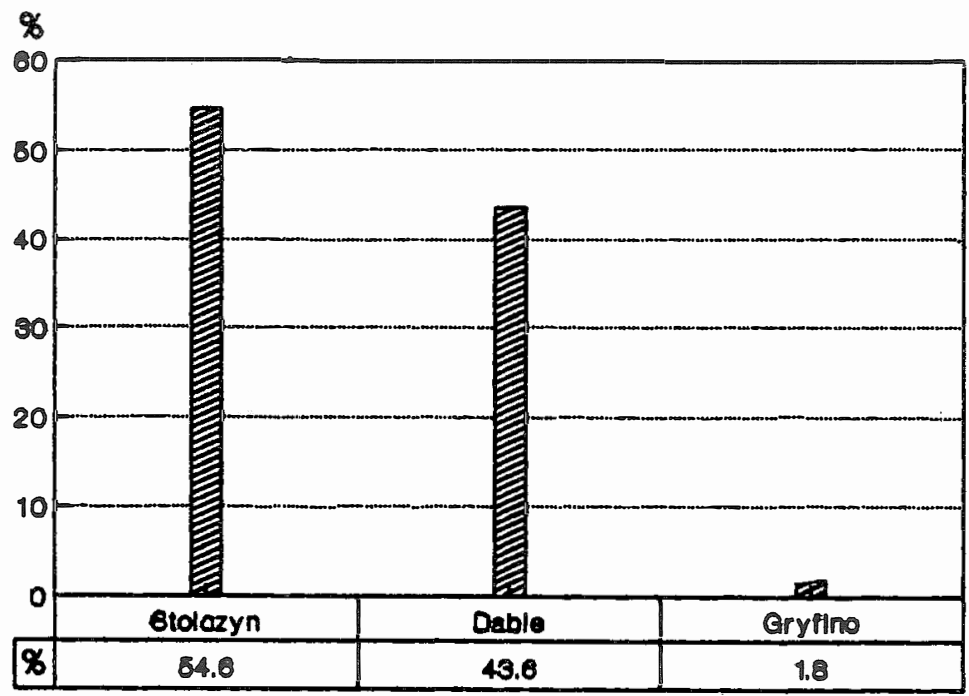

Fig. 12. Share of sea trout and salmon catches in Polish part of the lower Odra divided into regions, for 1973-1987 (sum of catches or 1973-1987 assumed as 100\%)

Szwedt, Wriezen and Frankfurt hardly $29 \mathrm{~kg}$ (12\%) (Tab. 2). It should be pointed out that the German fishermen catch fishes over a markedly smaller water surface of the lower Odra as compared with the area being at the disposed of Polish fishermen. In conclusion it may be ascerained that $99.75 \%$ of salmon and sea trout catches in the lower Odra are carried out by Polish fishermen, while $0.25 \%$ by German ones. 


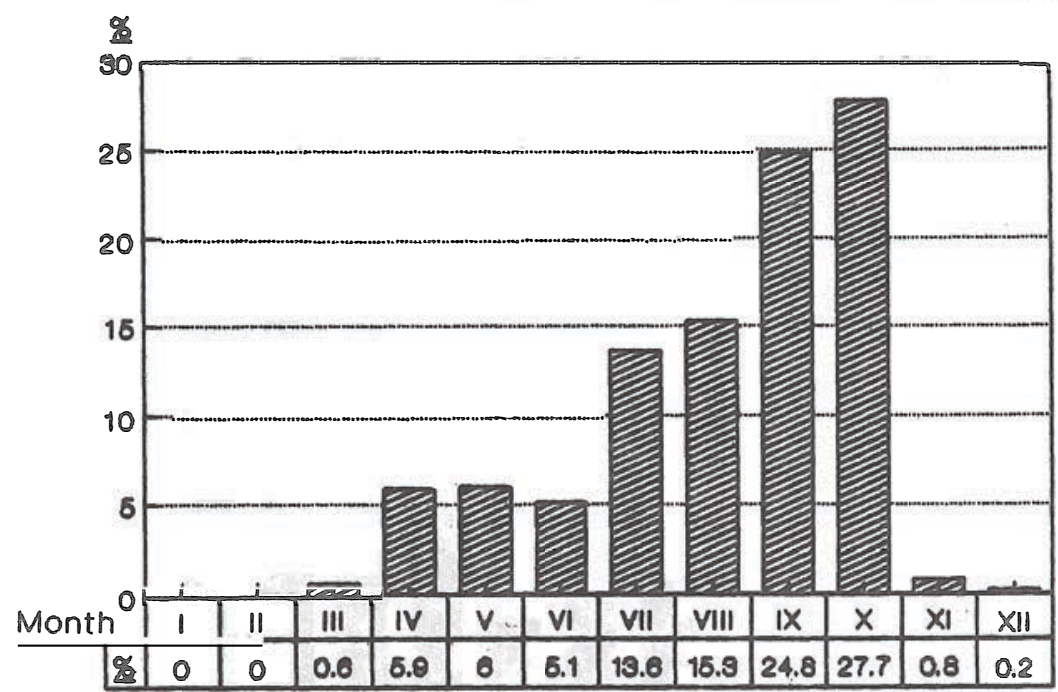

Fig. 13. Share of sea trout and salmon catches in Polish part of the lower Odra in months for 1973-1987 (sum of catches for 1973-1987 assumed as 100\%)

The pattern of shares in catches ascribed to Polish fishermen in regional division of the lower Odra, for the studied period, is depicted in a diagram (Fig. 12). The highest sea trout and salmon catch occurred in the region of Stolczyn (6406.5) (54.6\%) somewhat lowe in the region of Dabie $5107.5 \mathrm{~kg}(45.6 \%)$ and the lowest in the region of Gryfino (213.6 kg; 1.8\%).

The structure of sea trout and salmon catches in the lower Odra by Polish fishermen in respective months is shown on the diagram (Fig. 13). It is disclosed that salmon and sea trout are appearing in catches from March to December. Within these months smaller catches occur in November, December and March, the share being $1.6 \%$, mediocre in April, May and June, claiming 17\%, and massive in July-October totalling $81.4 \%$, the highest catch was registered in October (27.7\%). No sea trout and salmon were found in January and February catches. The contribution of Polish fishermen in monthly arrangements for three regions in the lower Odra is displayed in the diagram (Fig. 14). In the Stolczyn and Dąbie regions the sea trout and salmon appear in MarchNovember catches, whereas in Gryfino region they are caught over the period of April-December. In Stolczyn and Dąbie regions small catches are recorded in March and November; mean ones in April-June while in July-October they are high. The biggest share in catches in Stolczyn region occurs in October and in Dabie as well as Gryfino regions that is achieved in September. 


\section{$\%$}

80

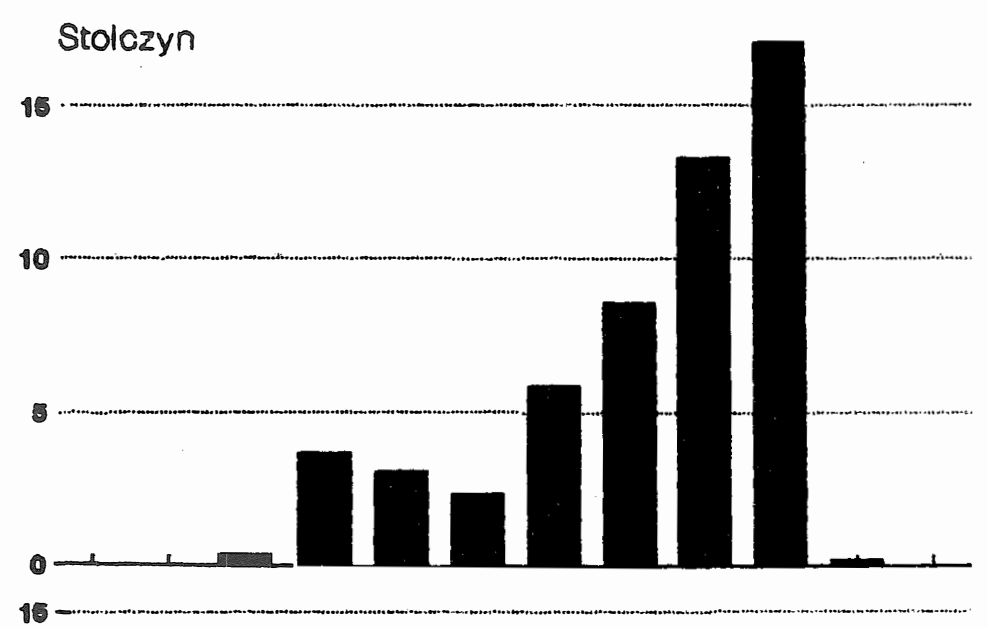

10 Dable

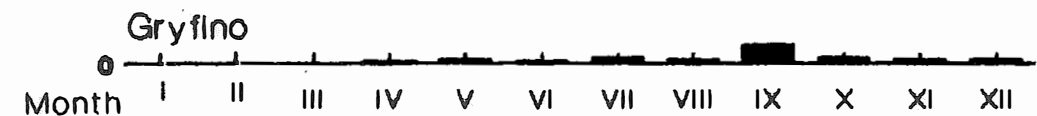

Fig. 14. Share of sea trout and salmon catches in Polish part of the lower Odra, divided into region and months for 1973-1987 (sum of catches for 1973-1987 assumed as 100\%)

\section{SALMON CATCHES IN DRAWA}

In the lower Drawa salmon were caught in November and December, being designed for reproduction of the population. The annual catches for 1973-1976 ranged from 20 to $126 \mathrm{~kg}$ (Tab. 1). During the period of studies the total of salmon caught in Drawa reached $334 \mathrm{~kg}$. 
Sea trout and salmon stocking of the lower Odra system in year 1973-1987

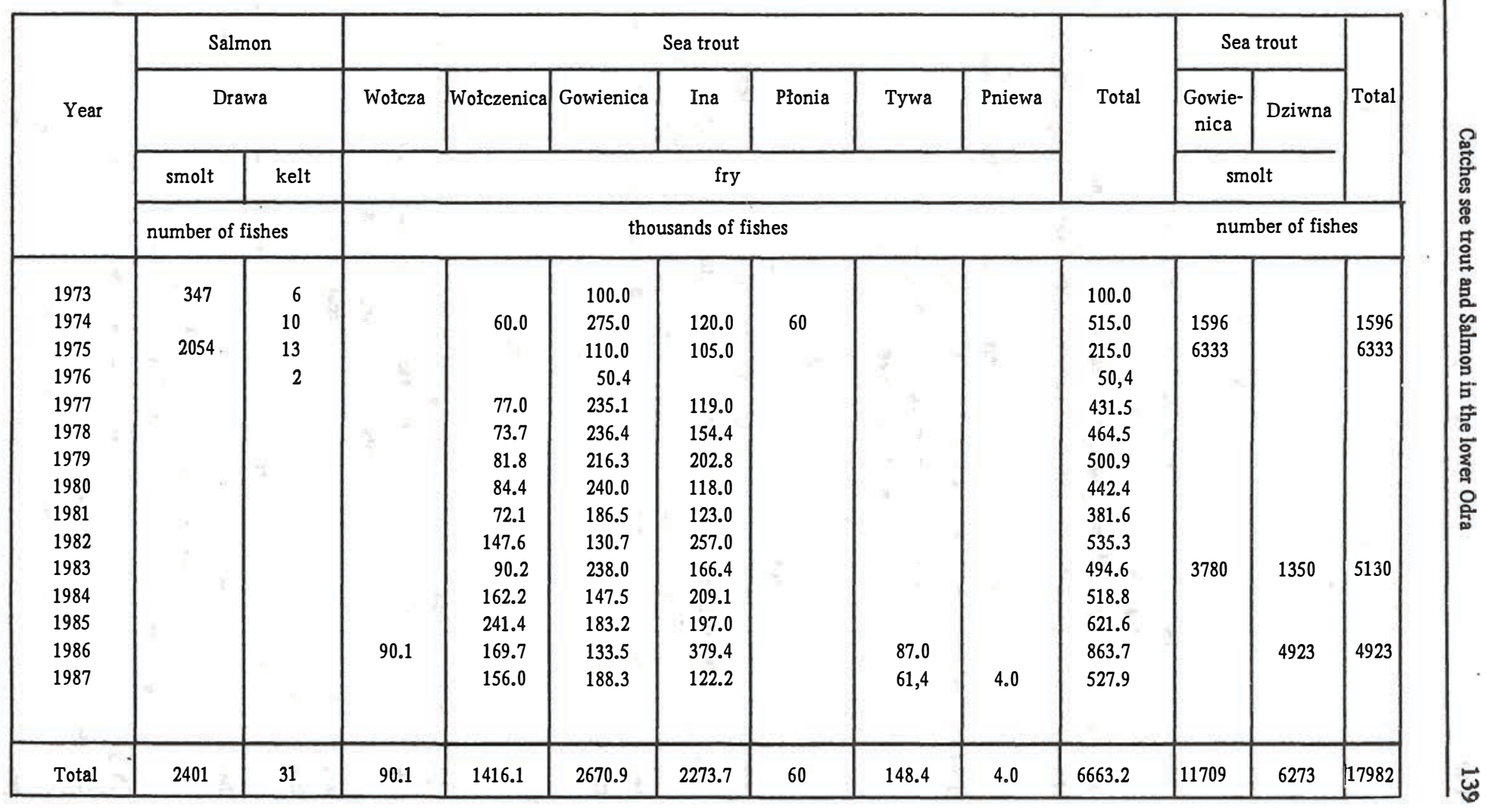


From 1977 onwards no catches of salmon were performed in Drawa. All attention was focussed on protecting the spawners and spawning places localized in the lower Drawa, and its left-bank tributary - Płociczna.

\section{STOCKING}

In the years 1973-1976 the lower Odra water system was stoched with sea trout and salmon. The accomplished stocking involved only the right-bank tributaries of Szczecin Firth, as well as tributaries of the lower Odra lying in the Polish areas. At the priod of studies the German did not stock the lower Odra water system with young sea-trout and salmon.

In January 1975, as many as 347 young fishes, aged $0+$ (presmolts) were released into Drawa, the latter was stocked again in spring of 1975 with 2054 two-year-old smolts, thereafter 31 salmon kelts were being released from 1973 to 1976.

Moreover, the tributaries of the lower Odra and Szczecin Firth were stocked in spring with fry and two-year-old sea trout smolts. The quantity of young population released in consecutive years into respective water-flows are depicted in Tab. 3. In 1973-1987 the total release in the lower Odra system involved 6.663.2 thousand of fry and 17.98 thousand sea trout smolts. The released young fishes and kelts of salmon originated from Drawa, while the hatched population and smolts of sea trout stemmed from parental forms found in the Pomeranian river Rege. The hatched population was released into streams of respective catchment areas, and the smolts as well as kelts into the lower parts of river-basins.

\section{COMMENT}

The annual sea trout and salmon catches in the lower Odra system during the studied period appeared to be more massive as compared with the earlier period.

Over the thirteen years (1960-1972) they oscillated within the limits of 1.4-3.7 tons (Chelkowski et al. 1976), and in the fifteen-year-long period of studies (1973-1987) they ranged from 1.9 to 9.6 tons.

The variation in the annual catches of sea trout and salmon in the lower Odra system for the period od 1960-1972 (after Chelkowski et al. 1976) as well as for the years 1960-1987 are displayed in the form of linear regression.

The regression coefficient $b=150.9$ is to prove that the catches during the period of 28 years (1960-1987) revealed a rising tendency, whereas their average annual increment was about $151 \mathrm{~kg}$ (Fig. 15).

According to Chełkowski et al. (1976) and the performed studies, it is apparent that sea trout and salmon catches in the lower Odra system for 28 years (1960-1980) 


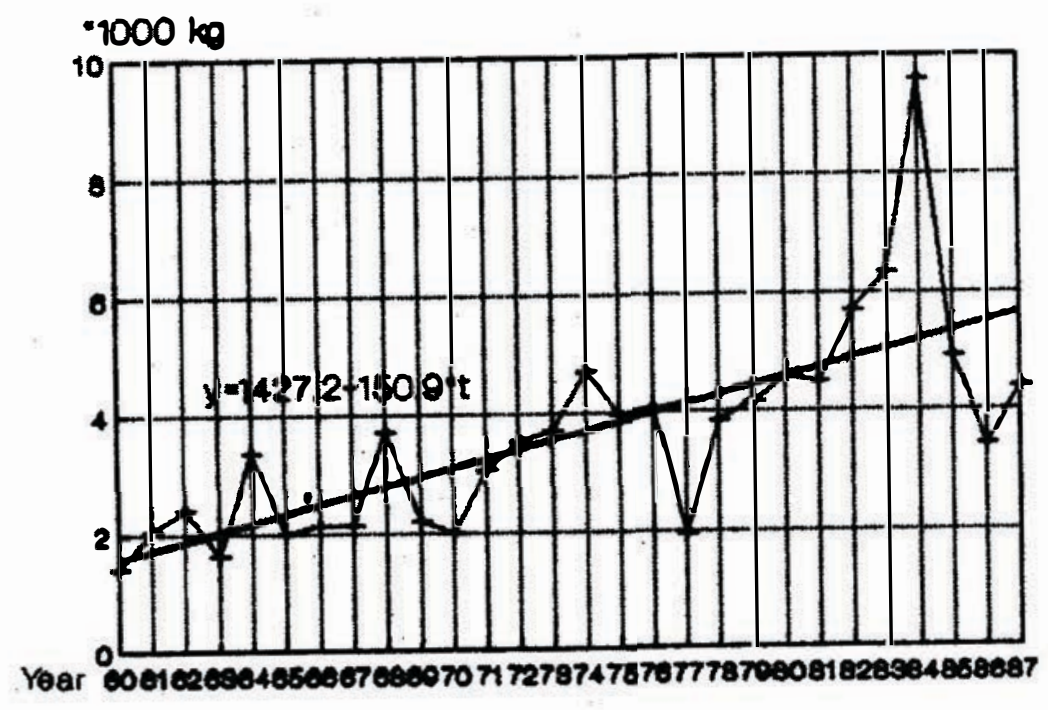

Fig. 15. Amount of see trout and salmon catches in the lower Odra system in 1960-1987

amounted to 101.24 tons, therein Polish catches $71.74 \mathrm{t}$ (70.9\%), and German ones $29.5 \mathrm{t}$. (29.1\%). Thus, the Polish catches in the lower Odra system at that period of time were 2.4 times larger than the German catches.

In some years before the Second World War the annual catches in Szczecin Firth oscillated, according to Talarczak (1971), between $0.1 \mathrm{t}$. to $0.5 \mathrm{t}$. but in the years 1960-1972, after Chelkowski et al. (1976), between 1.3 t. to 3.2 t., and during the studied period between 1.6-7.6 t. In the lower Odra, however, over the period of 1960-1972, according to Chełkowski et al. (1976) the annual catches ranged from 0.1 to $0.5 \mathrm{t}$., while over the studied period, between $0.3-2.0 \mathrm{t}$.

The average annual catch of sea trout and salmon in Szczecin Firth, after Chelkowski et al. (1976) claimed for 1960-1972 as many as $2.1 \mathrm{t}$. and $3.8 \mathrm{t}$. for the years being studied. However, the average annual catch of sea trout and salmon in the lower Odra was $0.27 \mathrm{t}$. at the first period and $0.8 \mathrm{t}$. for the second period, that being stated by the above-mentioned authors. As results from the data provided by Chelkowski et al. (1976) as well as from the performed studies, the catches of sea trout and salmon, carried out in the entire Szczecin Firth for the years 1960-1987, achieved $84.95 \mathrm{t}$. wherein the Polish catches recorded 55.48 t. (65.3\%) and German ones 29.4 t. (34.7\%). The sea trout and salmon catches in the lower Odra during 1960-1987, quoted after Chełkowskl et al. (1976) and in the studies amounted to 15.25 t., where of the Polish catches -15.09 t. (98.4\%) and those by Germans -0.25 t. (1.6\%).

The ratio of Polish catches to German catches in the Szczecin Firth throughout the consecutive, comparative years highlights rather an interesting phenomenon. So 
according to Chełkowski et al. (1976) the relevant studies make it apparent that in 1960-1968 (except the year 1967) the German catches of sea trout and salmon were larger in relation to Polish catches, while in the years 1969-1987 and 1967 the catches accomplished by Polish were larger as compared with German ones. Moreover, it is noted that the shares of German catches versus the Polish over the period of 1960-1987 are decreasing, and in this way, the Polish catches are going up. For instance, in 1961 the share of German catches reached 91.5\%, the Polish being 8.5\%, however, in 1967 the share of Polish catches scored $89.4 \%$ and the German barely $10.6 \%$.

The shares of catches involving sea trout and salmon in the whole of Szczecin Firth for the years 1960-1972 (Chełkowski et al. 1976) and those in the study materials appeared to be similar. High shares of catches at the two periods occurred in AprilOctober, and the low catches were evidenced in November. However, the shares of catches differed in some months. The highest share of catches, recorded in the material for 1960-1972 appeared in July, but in the studied material that happened in September, thus two months later. However, the sping elevation in shares of catches accomplished in April was ascertained in both periods being compared. A similar pattern of shares for catches of salmon and sea trout in monthly arrangements for the lower Odra is displayed in data covering the years 1960-1972 (Chełkowski et al. 1976).

At the two periods, the highest catches were achieved in September and October, medium in April-August, and the lowest in November. But during the 1960-1972 period, the highest share of catches was encountered in September (29.4\%); slightly smaller in October (25.2) however, the findings were reversed during the periods studied, the highest share of catches was seen in October (27.7\%) and lower in September (24.8\%).

As it is apparent from the study material, the highest share of catches accomplished in Szczecin Firth had been stated in September, and in the lower Odra waters, more farther from the sea, the highest share of catches shifted to October - one month later.

The pattern for the shares in catches of the sea trout and salmon with reference to Polish and German exploits in Szczecin Firth during consecutive months of the year turned out to be characteristic too. In 1960-1972 (Chełkowski et al. 1976) the German share in catches during the first 8 months of the year (January-August) was the highest in relation to Polish catches; while in the remaining months of the year (September-December) the Polish share in catches was greater than the German one. However, in the studied material (1973-1987) a higher German share compared with the Polish catches was discerned in February and November, whereas in other months of the year (March-October and December-January) the Polish share in catches was uperior. It should be noticed that salmon and sea trout in the Polish part of Szczecin Firth, up to 1980 , were under protection in the months of November and December, which was not the case in the German part of Szczecin Firth.

The shares in catches of sea trout and salmon in 10 regions of the Polish part of Szczecin Firth during 1960-1972 (Chełkowski et al. 1976) differed somewhat from 
those established at the period of study. Nevertheless, both at the first and the second period most massive catches were performed in the Kamien and Trzebiez regions. It is worth mentioning that the shares in catches in the two regions, at the studied time, in relation to the period of $1960-1972$, increased in the former region by $6.4 \%$, and in the latter by $9 \%$.

Moreover, it may be detected that a relatively high share in catches ascribed, for the years 1960-1972, to Stepnica region markedly diminished during the study years. At the same time the Lubin region was found to have significantly raised its share in the catches. In relation to 1960-1972, the shares in catches made in the remaining five regions in the Polish part of Szczecin Firth, during the study period and that being compared, were found to be similar. It is still possible to compare the shares in catches accomplished in the lower Odra for 1960-1972 (Chełkowski et al. 1976). One can observe that both in the first and the second period, the most substantial share in catching sea trout and salmon was claimed by Stolczyn region, and a bit smaller by Dąbie region, the smallest being recorded in Gryfino region.

The shares in catches of sea trout and salmon in the individual regions of the lower Odra system in the months of 1960-1972 (after Chełkowski et al. 1976) as well as during the study period had assumed a similar pattern outlines. The highest share in catches in the overwholming number of regions was observed to be in September, in some regions - October. High shares in catches appear in July-August. In April there is an increase in the shares of catches in all the regions concerned. The smallest shares in catches are recorded in January, November and December.

Salmon were present in catches in Drawa river, according to Chełkowska (1982) and demonstrated by the studies in the years 1961-1976. Annual catches of salmon in 1961-1972, after the cited author, calculated on the basis of the mean mass of gutted kelts, multiplied by the number of fishes, ranged from 10.2 to $550.8 \mathrm{~kg}$, and at the time of studies i.e. 1973-1976, from 20 to $126 \mathrm{~kg}$. The sea trout were also recorded, but sporadically, in the Drawa river catches.

As it is apparent from the presented Table 3 comprising materials and data provided by Chełkowski et al. (1976) the stocking campaign with young salmon in Drawa system referred to the years 1948-1975. At that period fish, older youth, and two-years-old smolts were released. On top of that, in 1968-1976 salmon kelts were released in the framework of perishing autochtonic species. The stocking with sea trout smolts of the lower Odra waters system was performed occassionally, using small quantities, during the period of studies as well as at previous periods (Chełkowski et al. 1976). According to the same sources of information the stocking with newly-hatched sea trout fry was done annually over the 1960-1987 period. However, in 1960-1972 lesser quantity of hatched fry was annually stocked as compared with 1973-1987. At the first period, an average of 161.4 thousand were annually released into the lower Odra system, while stocking at the second period was 2.8 times more profuse ( 444.8 thous). The amount of 
Number of sea trout and salmon fry to be released into studied basin of the lower Odra and Szczecin Firth

\begin{tabular}{|c|c|c|c|}
\hline \multirow{2}{*}{ Name of basin. } & \multicolumn{2}{|c|}{$\begin{array}{l}\text { Batch thousand } \\
\text { of fish }\end{array}$} & \multirow{2}{*}{ Author } \\
\hline & from & to & \\
\hline 1. Woĺcza & 47.4 & 94.8 & $\begin{array}{l}\text { Chełkowski Z., Filipiak J., Trzebiatow- } \\
\text { ski R.: } 1984\end{array}$ \\
\hline 2. Wolczenica & 123.4 & 246.8 & $\begin{array}{l}\text { Chełkowski } Z_{\text {. }} \text { Filipiak J., Trzebiatowski } \\
\text { R.: } 1984\end{array}$ \\
\hline 3. Gowienica & 180.9 & 361.8 & 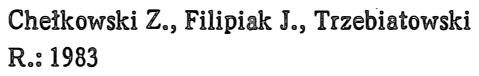 \\
\hline 4. In8 & 232.6 & 465.1 & $\begin{array}{l}\text { Chelkowski } Z_{\circ} \text { Trzebiatowski } R_{\circ} \\
\text { Filipiak J:: } 1986\end{array}$ \\
\hline 5. Płonia & 211.2 & 422.4 & $\begin{array}{l}\text { Chelkkowski Z., Trzebiatowski } R_{\text {., }} \\
\text { Filipiak J.: } 1989\end{array}$ \\
\hline 6. Tyพ8 & 91.7 & 183.5 & $\begin{array}{l}\text { Chełkowski Z., Trzebiatowski R., } \\
\text { Filipiak J.: } 1987\end{array}$ \\
\hline 7. Pniewa & 4.8 & 9.6 & $\begin{array}{l}\text { Chełkowskẻ Z., Domagaỉa J., Trzebiatow- } \\
\text { ski R., Ciupinalki M.: } 1989\end{array}$ \\
\hline 8. Ruszyca & 25.4 & 50.7 & $\begin{array}{l}\text { Chełkowski Z., Filipiak J., } \\
\text { Trzebiatowski R., Ciupiniski. M.; } 1989\end{array}$ \\
\hline Total & 917.4 & 1834.7 & \\
\hline
\end{tabular}

the released fry during the first period oscillated annually from 55 to 440 thous, at the second - from 50.4 to 873.7 thous. In conclusion, it may be stated that over the period of 1960-1987 the amount of fry released into the lower Odra system had an upward tendency, which undoubtedly exerts adequate influence on the increase in catches mainly of sea trout in Szczecin Firth and in the lower Odra.

The performed classification of certain partial basins of the lower Odra system, lying on the Polish side, aimed at finding out whether there is any possibility to exploit them for natural smolt production. They offer conditions for markedly increasing the stocking with sea trout fry as compared with that hitherto implemented.

As shown by data depicted in Table 4, the investigated streams draining into the lower Odra and Szczecin Firth are suitable to be stocked annually with 1834.7 thous. sea trout fry. Hence, the stocking compaign involving hatched fry may be elevated 4.1 
fold in relation to the average releases for 1973-1987. It can be assumed that for growing the sea trout and salmon youth from the moment of the fry release to the smolt age, some other streans in the basin of Odra system should be taken into consideration. It is doubtless that the augmentation of stocking the properly selected waters of the lower Odra system with hatched fry or smolts of sea trout or salmon may increase the catches in Szczecin Firth and the lower Odra.

\section{CONCLUSIONS}

The annual catches of salmon and mainly of sea trout in the lower Odra system, in 1973-1987, ranged from 1.9 to 9.6 t. At the same time the yearly catches in the lower Odra oscillated from 0.3 to $2.0 \mathrm{t}$. and in Szczecin Firth from 1.6 to 7.6 t. The calculated coefficient of regression $b=+147.5$ indicates that primarily sea trout and salmon in the lower Odra system displayed the tendency to rise, whereas their annual average increase was $148 \mathrm{~kg}$.

In the analyzed years the catches of sea trout and salmon in the Polish part of Szczecin Firth reached $76.3 \%$, and in the German - 23.7\%.

The steadily increasing catches of chiefly sea trout in Szczecin Firth and the lower Odra are due to increased stocking with sea trout fry being released into the basin of rivers draining into the lower Odra and Szczecin Firth on the Polish side. As it is evidenced by the elaborated materials, at the period from 1973 to 1987 , the mentioned river basins were annually stocked with from 50.4 to 863.7 thous. sea trout fry. The stocking of the lower Odra system waters throughout the years of analyzed catches was accomplished exclusively by the Polish part.

It seems to be purposeful for the fishermen's benefit on both sides, that the stocking with young sea trout and salmon should be carried out by the German side too.

Sea trout and salmon after growing in the sea enter Szczecin Firth in waters of Dziwna, Piana and also Swina regions, which is illustrated by monthly distributions of shares in catches of these fishes in the mentioned areas.

The spawning migration of sea trout from the Baltic to Szczecin Firth takes place in January-December, but principally March-October. At this period two intensifications of migrations are observed - less intensive in April and more pronounced in September.

The introduction of uniform regulations for the protection of sea trout and salmon in the lower Odra system involving the German part and Polish one seems to be fully justified, too.

\section{REFERENCES}

Bartel $\mathbb{R}_{0}, 1987$ : Distribution, migration and growth of tagged Drawa salmon (Salmo salar L.). Journal of applied ichthyology. B.3 - H.1: 33-38. 
Bartel $R_{0}$ Z Z Zielioaski: Sprawozdanie z serwisu informacyjnege gospodarki iososiowej za 1973-1985. [Report of information service. cons. salmon fishery for 1973-1985]. IR $\dot{S}$ - Zakład Upowszechniania Postępu (in Polish).

Chellsonsalsa Bog 1982: Studies on morphology and biology of salmon Salmo salar L。 in the river Drawa. Acta Ichth. Piscat. XII Suppl.

Cheilkowsica Bo, Z. Chelltowska, 1974: Eosos w Drawie (VIII). [Salmon in the Drawa VIII]. Gosp. ryb., 10: 20-21. (in Polish)

Cheilkowska Bo, Z. Cheellsowski, 1975: Eosoś w Drawie (IX). [Salmon in the Drawa]. Gosp. ryb., 8/9: 27-29. (in Polish)

Cheillsowaka Bo, Z. Cheilsowsiki, 1976: Losos w Drawie (X). [Salmon in the Drawa]. Gosp. ryb., 7: 19-21. (in Polish)

Cheillowaski $\mathbb{Z}_{\circ}$, 1966: Introdukcja troci do rzeki Gowienicy. [Introduction of sea trout into Gowienica river]. Gosp. ryb., 1: 18-19 (in Polish).

Cheillowaki $\mathbb{Z}_{\text {og }}$ 1971: Połowy łososia i troci w rzekach pomorskich. [Salmon and sea trout catches in Pomeranian rivers ]. Gosp. rybo, 10: 15-19. (in Polish).

Cheriltowaka Z $\mathbb{Z}_{0}$ 1977: Losos $w$ Drawie (XI). [Salmon in the Drawa]. Gosp. ryb., 9:17-19. (in Polish).

Cheillowski Zo, 1987: Występowanie lososia (Salmo salar Lo) w Zalewie Szczeciñskim i w dolnej Odrze oraz jego ochrona. [The occurrence of salmon (Salmo salar $\mathrm{L}_{\text {. }}$ ) in the Szczecin Lagoon and downstream Odra and protection of the species]. Szczeciñskie Roczn. Nauk. II/2: 53-71. (in Polish, English summary).

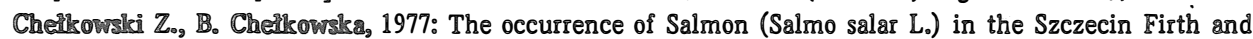
Lower Odra in 1974. Acta Ichth. Piscat. 7, 2:3-8.

Cheilkowsici Zos. Cheilkowsika, 1978: Occurrence of Salmon (Salmo salar $L_{0}$ ) in the Szczecin Firth and Lower Odra in 1975. Acta Ichth. Piscat. 8, 1:23-28.

Cheilkowsalai $\mathbb{Z}_{\circ}$ B. Cheilleowsika, 1979: Occurrence of Salmon (Salmo salar $L_{0}$ ) in the Szczecin Firth and Lower Odra in 1976. Acta Ichth. Piscat. 9, 2:15-20.

Cheillsowski Zog B. Chellsowsisa, 1980: On the occurrence of Salmon (Salmo salar Lo) in the Szczecin Firth and Lower Odra in 1977. Acta Ichth. Piscat. 10, 1:59-64.

Cheilkowski $\mathbb{Z}_{\circ}$, B. Chellsowaka, $\mathbb{H}_{0}$ Kisielnicka, 1976: Salmon (Salmo salar $\mathrm{L}_{0}$ ) and trout (Salmo trutta $\mathrm{L}_{0}$ ) fishing and stocking in the Lower Odra river system. Acta Ichth. Piscat. 6, 1: 143-159.

Cheilkowski Zo, B. Cheitlowalka, H. Kisielnicka, 1976a: The occurrence of Salmon (Salmo salar Lo) in the Szczecin Firth and Lower Odra in 1973. Acta Ichth. Piscat. 6, 2: 55-62.

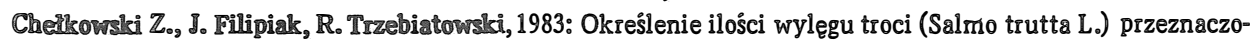
nego do zarybiania zlewni rzeki Gowienicy. [Quantitative determination of sea trout fry (Salmo trutta) designed, for stocking the Gowienica river basin ]. Akademia Rol. Szczecin 9 pp. (in Polish).

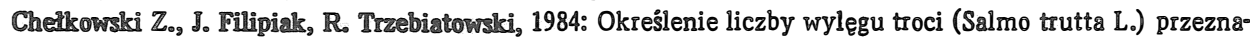
czonego do zarybiania cieków zlewni Wolczy. [Quantitative determination of sea trout fry designed for stocking Wolcza catchment]. Akademia Rol. Szczecin, 6 pp. (in Polish).

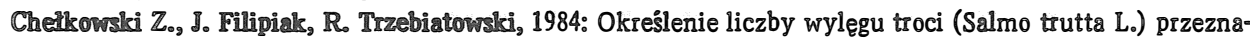
czonego do zarybiania cieków zlewni rzeki Wolczenicy. [Quatitative determination of sea trout fry designed for stocking Wołczenica catchment]. Akademia Rol. Szczecin 6 pp (in Polish).

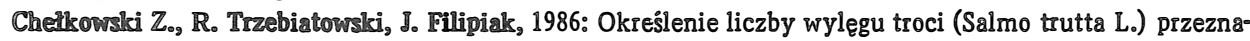
czonego do zarybiania cieków zlewni Iny. [Quantitative determination of sea trout (Salmo trutta) fry designed for stocking Ina catchment ]. Akademia Rol. Szczecin, 9 pp. (in Polish).

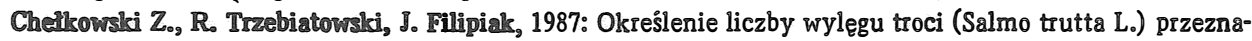
czonego do zarybiania cieków zlewni Tywy. [Quantitative determination of sea trout (Salmo trutta) fry designed for stocking Tywy catchment ]. Akademia Rol. Szczecin, 7 pp. (in Polish).

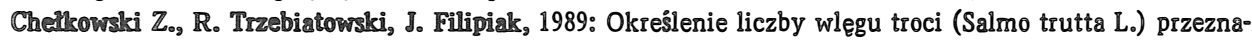
czonego do zarybiania cieków zlewni Płoni. [Quantitative determination of sea trout (Salmo trutta) fry designed for stocking Plonia catchment ].Akademia Rol. Szczecin, 5 pp (in Polish).

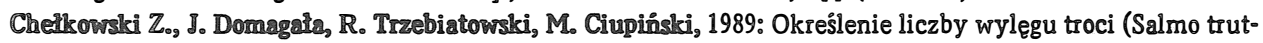
ta L.) przeznaczonego do zarybiania cieków zlewni Pniewy (prawobrzeżnego dopływu Odry). [ Quanti- 
tative determination of sea trout (salmo trutta) fry designad for stocking Odra right bank tributary]. Aka. demia Rol. Szczecin, 9 pp. (in Polish).

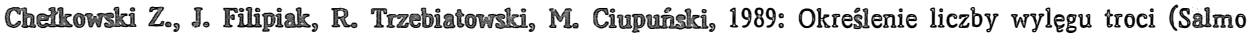
trutta L.) przeznaczonego do zarybiania ciekơw zlewni Rurzycy (prawobrzeżnego dopływu dolnej Odry). [Quantitative determination of sea trout (Salmo trutta) fry designed for stocking the lower Odra right bank tributary]. Akademia Rol. Szczecin, 5 pp. (in Polish)。

Ronanowalci Wo, 1951: Zastosowanie statystyki matematycznej w dosiwiadczalnictwie. [ Use of mathematical statistics in experiments]. Pol. Wydawn. Gospodarcze T. XIII. Seria Biblioteka Statystyki. Warszawa, pp. 229 (in Polish).

Talarczals $\mathbb{K}_{0}$ 1951: Ryboloowstwo na Zalewie Szczecinskim. [Fishery at the Szczecin Firth]。Gdañsk pp.96 (in Polish).

Translated: Piotr Filipczyk

\title{
Zygmunt CHEZKOWSKI
}

\author{
POEOWY TROCI (SALMO TRUTTA L。) I EOSOSIA (SALMO SALAR L。) \\ W SYSTEMIE DOLNEJ ODRY ORAZ ZARYBIANIE W LATACH 1973-1987*
}

\section{STRESZCZENIE}

W pracy przedstawiono i analizowano polowy troci (S. trutta Lo) i lososi (S. Salar L.) rybakoow polskich i niemieckich w Zalewie Szczecin̊skim i dolnej Odrze oraz rybakơw polskich w Drawie - stanowiącej czwartorzędowy dopływ Odry w piętnastu latach (1973-1987). Obydwa gatunki ryb musiały być traktowane łącznie tak jak to jest w gospodarczych statystykach, ktoore były żrodlem informacji o polowach. Polowy troci i lososi w systemie dolnej Odry w analizowanych latach wynosiły ogơłem $69,675 \mathrm{~kg}$ w tym w Zalewie Szczecinskim $57,584 \mathrm{~kg}$, dolnej Odrze $11,757 \mathrm{~kg}$ oraz w Drawie $334 \mathrm{~kg}$. Pollowy w kolejnych latach badan wahaly się w dos̊c szerokich granicach 1,9 do 9,6 t. Natomiast s̊redni połöw roczny wynosi 4,5 t. $Z$ obliczonego równania prostej regresji wynika, że roczny przyrost wysokossci polowơw lososi i troci w systemie dolnej Odry w latach 19731987 wyniỏsł około $148 \mathrm{~kg}$. Zwiększające się polłowy, glơwnie troci, w Zalewie Szczecin̊skim i dolnej Odrze sब wynikiem wzrastających zarybieñ wylęgiem troci zlewni rzek uchodzących do dolnej Odry i Zalewu Szczecin̊skiego po polskiej stronie. W latach 1973-1987 wsiedlano rocznie do wymienionych zlewni od 50,4 do 863,7 tys. sztuk wylęgu troci. Zarybianie wood systemu dolnej Odry w latach analizowanych połowơw dokonywaìa tylko strona polska. Wydaje się celowym dla dobra rybalơw obydwu stron, aby zarybianie miodzieżę troci i lososia dokonywalła i strona niemiecka. Trocie i łososie po wyrośnięciu w morzu wstępują do Zalewu Szczeciñ skiego wodami Dziwny, Piany a także Świny, na co wskazują rozkł̇ady miesięcznych udziałơ połowơw ryb w wymienionych rejonach.

Wędro̊wka tarł’owa troci z Bẩtyku do Zalewu Szczeciñskiego rozciagga się głoownie na marzec-październik. W analizowanych latach połowy lososi i troci w niemieckiej częsei Zalewu Szczeciñskiego wynosiły 23,7\% a w polskiej $76,3 \%$ 。

* praca wykonana i dotowana w problemie RR-II-20

Authors' address:

Received: 1991.02.19

Prof. dr hab. Zygmunt Chełkowski

Zakład Gospodarki Łososiowej

Akademia Rolnicza

ul. K. Kro̊lewicza 4

71-550 Szczecin

Polska (Poland) 